\title{
Informal settlements in Baghdad city
}

\author{
Anastasia Repeva* \\ Moscow State University of Civil Engineering, Yaroslavskoe shosse, 26, Moscow, 129337, Russia
}

\begin{abstract}
The research deals with the issue of slums, urban sprawl on agriculture land and its impact on the city of Baghdad. This topic needs close attention because it has become a problem facing the city of Baghdad through recruiting agricultural lands and converting them to residential homes in addition to the transgression on the state lands and building abuses.

This research deals with the causes of slums, irregular urban sprawl and risks of excesses on land uses of land in Baghdad. In this research, we try to know the extent to which these problems have affected the city of Baghdad.

The research methodology based on the descriptive methodology to clarify the factors affecting urban sprawl at the expense of agricultural land, using studies in government and service institutions and images from satellites to clarify the size of urban sprawl over periods after the 2003 war. Finally, a conclusion and future solutions were set to solve these problems.
\end{abstract}

\section{Introduction}

Informal settlement ${ }^{\dagger}$ is becoming one of the biggest problems in the world nowadays.

\footnotetext{
*Corresponding author: lilit_89@mail.ru
}

†Informal settlements are areas where groups of housing units have constructed on land that the occupants have no legal claim to, or occupy illegally. [7]

One of names that call for the processes of building informal houses illegally. It has shown the causes of rapid population growth in many cities across the developing world. There are several names but all of them share the same processes, such build, development, and add on it, all of that have done by the family and they depend on their self-help. [6]

Arabic institute defined that (slums) houses built without permitting on area owned by the government or owned by others. Those houses often built in the area where there are no government services due to donate the government. [8]

The definition of informal settlements is context-specific. Various definitions have thus been proposed, but the one that suggested by the UN Habitat Program is probably the most widely applicable. This defines informal settlements as: i) residential areas where a group of housing units has been constructed on land to which the occupants have no legal claim, or which they occupy illegally; ii) unplanned settlements and areas where housing is not in compliance with current planning and building regulations (unauthorized housing). [9]

Therefore informal settlements are residential areas and they are not included in urban planning for the city contained illegal houses in territories deprived of public facilities and basic services. The images and shapes of these areas have been multiplied and spread on the outskirts of cities at first, then gradually leaked to the suburbs and then to the interior. These areas have arisen in the absence of general planning for cities and out of the laws of regulating urbanization. 
An estimated 1.6 billion people live in inadequate housing globally, of which 1 billion live in slums and informal settlements. [9] This means that about one in four people in cities lives in conditions that harm his health, safety, prosperity, and opportunities. The aforementioned problems are difficult to solve day after day. That reflected on the creation of serious obstacles to the process of urban development, which has a dangerous impact on the cities in the developing world in ways of economic, society and security. The number of reasons of this problem requires involving different specialists in many fields, including social economics, planning, architecture, and environmental, to work through it. Iraq as other countries where urban development did not take its way in a balanced manner, where has been created many serious difficulties for the process of development and severe damages in the housing environment in general. Informal settlement appeared in this country in various and different stages and forms, which affected the functional structure of cities and morphological in a way that cannot be ignored. An unusual growth in the size of slums has witnessed over the last several years, and it remains difficult to control this growth. In an observation, that made by the Iraqi Government, was found that there are more than $12 \%$ of Iraqis live in slums, that means more than two million people live in slums. Iraq did not testify informal settlement like this before 2003, but with security issues besides the high rising of poor, bush them to settle one undeveloped land, and they built cheap houses without planning.

\section{Methods}

\section{Urban land use}

Land use plan is the result of the visual processes of urban planning which follow urban planning policies and has written results for these processes. Land use plan is the result of the visual processes of urban planning which follow urban planning policies and has written results for these processes. A series of procedural link with each other, which need to develop and implement with a view to optimizing land use through the study and evaluation of all existing and relevant economic and natural factors. [3]

Urban land use reflects the location and level of spatial accumulation of activities such as retailing, management, manufacturing or residence. They generate flows supported by transport systems. [1]

The division of cities into multiple areas with different uses is a planning pattern known since ancient times. One part provides the main function as well as secondary functions that complement the main function. [2]

The most important characteristic of the land use plan refers to the locations of the processes as it refers to the different uses. However, it does not specify the location of the school or the hospital, although it gives and clarifies the relationships and principles of its own and its location.

\section{Risks of excesses on land use}

Indiscriminate land use leads to many problems, including economic, social and planning, and it ultimately leads to the deterioration and decline of cities and the presence of rival between different uses. The goal is to serve citizens in the present and the future, to organize their lives and provide resources, to give a beautiful picture of the city. The most important risks that arise from the overuse of land use:

Urban risks and urban fabric distortion: This manifested by the indiscriminate use by citizens and their lack of commitment to planning laws and regulations. The planning committees issue the building permissions. We find that there is a group of houses built without permissions and there is an overlap in the uses. This, in turn, leads to the distortion 
of construction and aging many demolished homes and the mismatch between the buildings styles used.

- Environmental and health risks: The proper planning of land uses ultimately leads to a phase in which the city avoids environmental and health risks if there is a commitment to what has planned. As if, there is slum or misuse, this leads to damage to the environment where a person lives.

- Economic risks: The structural plans prepared by the responsible institutions to organize the life, welfare of the citizen, achieve the interests of the individual and society. This, in turn, leads to costs borne by the responsible parties, these costs will be waste if they are not used, and that is after the citizen's commitment to the applicable laws. Likewise, the citizen will bear a portion of these costs if he does not abide by the applicable laws and regulations, the citizen will bear an additional cost to deliver the services or find alternatives in the event that the services do not reach them. [4]

- Security risks: the competent authorities prepared the structural plan. The goal is the welfare and security of the citizen, and being away from the risks that cause harm to the human. Therefore, these risks should be take into consideration and avoided as far as possible, and that comes through optimal use.

- $\quad$ Social risks: Social risks arise from a citizen's failure to comply with building and regulation laws, which threatens social security and disrupts society and its unity. [5]

\section{Research hypothesis}

1. Baghdad city suffers from informal settlement. This informal settlement is due to several reasons.

2. It is possible to work to address the problem of informal housing as well as the possibility of developing its urban environment.

Spatial prudery:

Spatial prudery includes for this research the municipality of Baghdad as shown in fig. (1). for temporal prudery, the research tries the historical development of the city in summery with a focus on the situation of the slum in nowadays. 


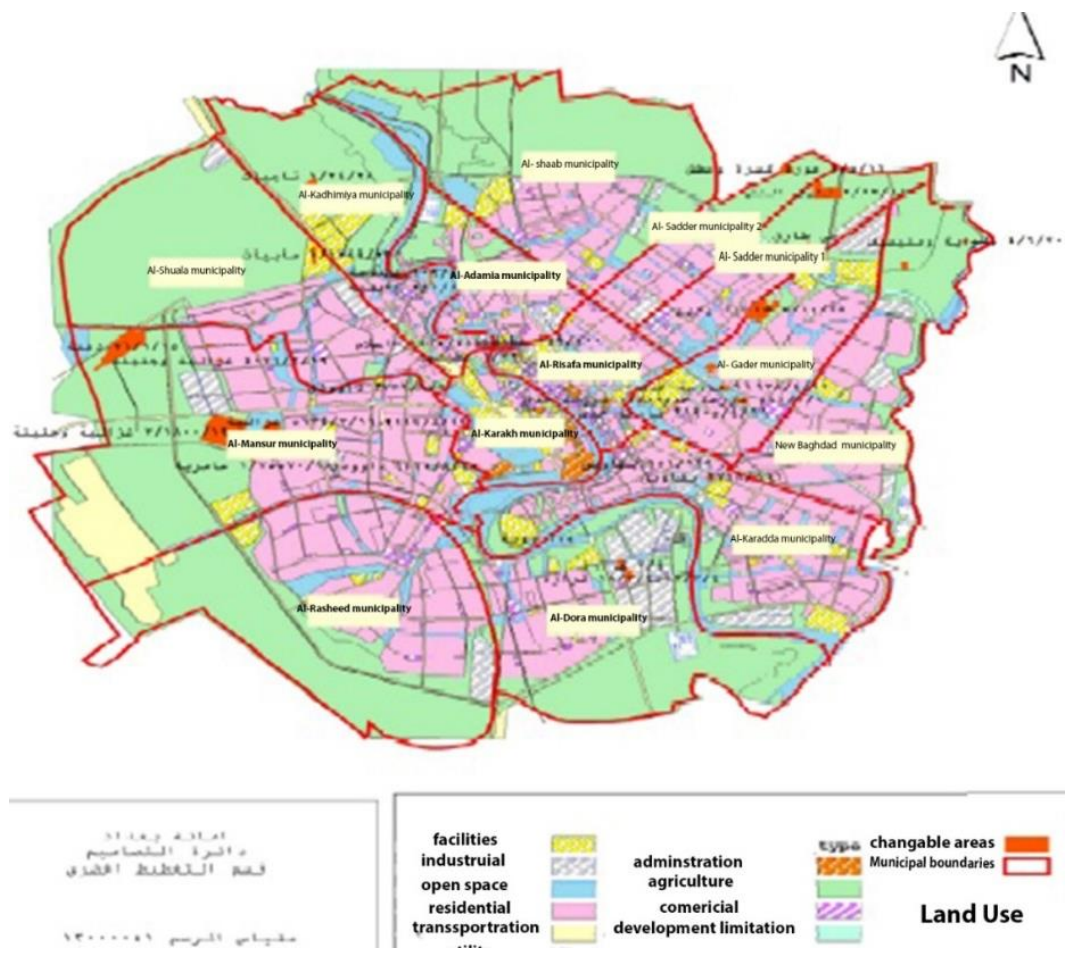

Fig. 1. Source: Baghdad Municipality, 2007, p.12

\section{Results}

The researches selected the case study of Baghdad green belt specifically close to AlShuala municipality. The mean reasons selection are:

1. The location is close to Baghdad borders, agriculture land that surrounded the city.

2. The area is located on the administrative boarders of Al-shuala municipality, that has poor infrastructures

3. The area classified as agricultural land.

4. Building type close to low cost housing

In the last few years, people have started building unlicensed houses on state-owned farmland, which led to a noticeable decrease in the area of agricultural land. These violations focus on the green area surrounded Baghdad, which greatly affects the city's environment. With the absence or weak implementation of the law, this phenomenon began to exacerbate, and lager residential districts devoid of services, which was formed adjacent to regular residential districts.

This region differs from other locations of slums, as it constructed using methods or materials that are similar to the methods used to construct residential houses in Baghdad and others. The houses cannot consider as temporary housing. Most of people who lives in the area are coming from extended families, which live in neighboring districts.

Due to the rapid growth of the population in general, with the fact of internal migration, the leak habitable housing, the failure of previous housing programs, with low income of a family, beside High real estate prices in regulated areas allocated for housing in the city. All these problems cause an increase in slums in Baghdad stems. The failure to keep pace with 
the different planning stages and basic plans for the needs of expansion in cities with emergency variables and the preparation of alternatives or plans accommodate of the population increase and housing problems. It led to continuing the phenomenon of informal housing and the expansion of the slums area especially in agricultural land that surrounding the City of Baghdad. The overriding extended to the properties of the various state institutions and even plots of land previously distributed to groups of citizens. Then, the presence of these informal housings increased in many areas of Baghdad city, and the residents built housing for them in plots of land within the existing residential neighborhoods, in areas and headquarters of military circles, military manufacturing facilities, mass organizations, and within the army camps, which made them clearly visible.

\section{Discussion}

There are several reasons that lead to slums and urban sprawl, including: a significant increase and growth in the population, weak deterrent laws and a move away from agricultural work, which leads to neglect and use of land in construction as well as material factors and the migration factor. That leads the urban sprawl and slums eliminate the green lands, which is necessary to purify environment of the city of Baghdad, where the green belts surrounding the cities are the last shield that stands in the face of environmental pollution

- Must of new houses were built on agriculture land.

- More than 70\% of houses were built in the year between 2010 and 2020 .

- The sprawl appeared scattered on the areas near formal residential then began expand.

- The households have good income and most of them work as government employees.

- Urban laws have a major role in reducing excessive agricultural land uses.

- The sprawl areas do not have infrastructure, schools, hospitals, police stations and other facilities, that can make them unhealthy and unsecure.

\section{Irregular urban sprawl on agricultural uses of land surrounding the city of Baghdad}

The problem of urban sprawl on agricultural lands is one of the problems that all countries over the world suffer from, especially those that have rapid population increases. Urban sprawl or suburban sprawl mainly refers to the unrestricted growth in many urban areas of housing, commercial development, and roads over large expanses of land, with little concern for urban planning.[16]

Urban sprawl in cities can be classified into two types; formal urban sprawl and Irregular or informal urban sprawl. The previous urban planning policy curtailed of the area of agricultural land in Baghdad, however this article forces on the irregular urban sprawl, which often translates into poor housing conditions, urban violence, lack of infrastructure, and a diversity of environmental hazards, including deforestation, poor sanitation, pollution of rivers and streams, and loss of biodiversity. [15]

Now days one of the biggest problems that face Baghdad is sprawl on agricultural uses. Agricultural lands that surround the city have reduced due to illegal sprawl and previous urban policies. That subject needs high attention because it became a problem by continuing informal sprawl and reduce the land, which has a high effect on the environment of the city. The agricultural land face pressure and reduce due to that sprawling and urbanization with urban law leaked that has bad effects on those lands. The urban in the city and around it symbolizes a life example that shows the sprawl on the agricultural lands. The city witnessed a huge extension in urban and in the same way reducing in agriculture land. 


\section{Conclusions}

1. Informal settlements have a serious problem that threatens the agricultural life and the green belt surrounding the city of Baghdad, as it led to a reduction in its area and consequently desertification.

2. Poor services and health care problems due to the lack of infrastructure services in these areas and surrounding areas.

3. Urban sprawl has a serious problem that threatens the agricultural life and the green belt surrounding the city of Baghdad. It led to a reduction in its area and consequently desertification, then it must limited.

4. Loss of large areas of agricultural land and green areas in the city, which have environmental impacts such as contributing to the desertification of the area.

In addition to many other problems and issues such as legal problems and other problems that effect on people live.

\section{Recommendations}

In order to reduce the informal settlements, the research recommends the following points:

1. Finding flexibility in implementing urban or environmental laws or reformulating it, especially in implementation and practical application. Identifying the authorities responsible for that, and separating or defining executive powers through a special committee in Parliament in cooperation with the Baghdad Municipality that is responsible for these laws.

2. Awareness-raising citizens about the problem of informal settlement and its danger, by distributing flyers and magazines to show its damages.

3. Work to reduce the granting of building permits in agricultural lands.

4. Encourage citizens to work in agriculture, invest agricultural land instead of neglecting it, and use it in construction. provide guidance to farmers who work in agriculture through modern farming methods, and how to use modern agricultural machinery in agriculture to obtain better production

5. There are ways to limit informal settlements, such as building houses vertically, not horizontally, to reduce the area of land used for construction, and work on construction in rough terrain that is not suitable for agriculture instead of building in agricultural land and following the policy of satellite cities.

\section{References}

1. Urban Land Use and Transportation/ Dr. Jean-Paul Rodrigue (https://transportgeography.org/?page_id=4613)

2. Baghdad Municipality, Comprehensive Perspective of the City of Baghdad in 2030, Analytical Study, 2014

3. Ghanim, Othman Mohammed, Rural and Urban Land Use Planning - General Geographic Framework, i. Amman. Jordan. Dar Safaa for Publishing and Distribution. 2001

4. Abu Hajir, Kawthar Shehada, Land Use Patterns Development in Jenin City During the Twentieth Century, Risala. Unpublished Master, An-Najah National University, Nablus, Palestine, 2001

5. Saleh Ahmad Saleh, organizational plans and the reality of land use in Dura city (governorate. Al-Khalil), Master's degree, College of Graduate Studies, An-Najah National University, 2004 
6. Lina Abdul Karim luxury, a former source, p. 6

7. OCED (https://stats.oecd.org/glossary/detail.asp?ID=1351)

8. Baghdad and after the geography, Journal of the College of Basic Education, AlMustansiriya University, Baghdad, No. 42361 UN-Habitat (2016). World Cities Report. UN-Habitat (2005). Financing Shelter

9. Sabah Fadel Al-Rahmani, Housing Policies and Planning, Dar Al-Hamid for Publishing and Distribution, Jordan, Amman, 3013, p. 45

10. Forced Migration ReviewRefugee Studies CentreDepartment of International Development3 Mansfield Road, Oxford OX1 3TB, UK. P.1 2007

11. Lina Abdul Karim Fakher, previous source, p14

12. Haider R. Azq Muhammad Al-Shabr al-Musawi, previous source, p. 16

13. Qassem Al-Ribdawi, The Problem of Random Residence in the Major Arab Cities, Damascus University Magazine, Volume 38, No. 1. 3013, p. 40.

14. Hanan Mahmoud Shukr Al-Jubouri, previous source, p. 19.

15. Fouberg, Erin Hogan (2012). Human geography: people, place, and culture. Murphy, Alexander B.; De Blij, Harm J. (10th ed.). Hoboken: Wiley. p. 560. ISBN 9781118018699. OCLC 752286985. 